\title{
Effects of extrusion operating conditions and blend proportion on the physico- chemical and sensory properties of teff-rice blend extruded products
}

\author{
${ }^{1}$ Minweyelet, M., ${ }^{2, *}$ Solomon, W.K. and ${ }^{3}$ Bultosa G. \\ ${ }^{1}$ Food process Engineering, Bahir Dar University, Ethiopia \\ ${ }^{2}$ Food and Nutrition Sciences, M205 Luyengo, University of Eswatini, Eswatini \\ ${ }^{3}$ Food Science Technology, Botswana University of Agriculture and Natural Resources, Private Bag 0027, \\ Gaborone, Botswana
}

\begin{abstract}
Article history:
Received: 24 August 2020

Received in revised form: 5 October 2020

Accepted: 17 November 2020

Available Online: 14 March

2021
\end{abstract}

Keywords:

Teff,

Rice,

Extrusion,

Optimization

\section{DOI:}

https://doi.org/10.26656/fr.2017.5(2).467

\begin{abstract}
The effects of extrusion conditions, teff-to-rice blend ratio (25-100\%), feed moisture content $(21-25 \%)$ and barrel temperature $\left(130-150^{\circ} \mathrm{C}\right)$ on the physico-chemical properties and the sensory attributes of extruded product from teff-rice blend was investigated. The physico-chemical properties (specific length, bulk density, expansion, water absorption index (WAI), water solubility index (WSI) and hardness), and sensory acceptability (flavor, color, texture and overall acceptability) were significantly $(\mathrm{p}<0.05)$ influenced by the extrusion conditions. Increasing barrel temperature resulted in higher expansion, lower density, reduced hardness and higher WAI, and WSI. Increase in the proportion of teff resulted in increased density, hardness, and WSI whereas increase in teff proportion brought about a decrease in expansion and WAI. Increasing feed moisture content resulted in higher density, lower expansion, higher WAI, lower WSI, higher hardness and lower crispness. The sensory scores reduced with increase in the proportion teff. The numerical optimization revealed that the optimal extrusion conditions for the best result were extrusion temperature of $150^{\circ} \mathrm{C}$, feed moisture content of $21.2 \%$ and blending ratio of $40 \%$ teff with a desirability value of 0.901 . The graphical optimization revealed that the best results were found between 140 to $150^{\circ} \mathrm{C}, 21$ to $22 \%$ feed moisture and 25 to $46 \%$ of teff proportion.
\end{abstract}

\section{Introduction}

Teff (Eragrostis teff [Zucc.] Trotter) is a major food grain in Ethiopia but is a minor cereal crop worldwide. It is an important cereal crop indigenous to Ethiopia and widely consumed by the population (Seifu, 1997; Bultosa and Taylor, 2004). Teff with its essential amino acids is nutritious as major staples like rice and oats and better than wheat and barley (Seifu, 1993; Gebremariam et al., 2014). The average length and width were reported to be 1.001 and $0.59 \mathrm{~mm}$, respectively and prolate spheroid in shape (Zewdu and Solomon, 2007).

The grain is ground to flour which is mainly used for making popular pan-cake like local bread called injera, porridge, unleavened bread, and several other products including beverages (Seifu, 1993; Gebremariam et al., 2014; Zhu, 2018). The high mineral content has made teff it an important ingredient in the baby food industry (Seifu, 1993; Zhu et al., 2018). Despite its measure contribution, the processing techniques and the types of food products made from teff remained to be limited.

The growing demand for gluten-free foods worldwide is an opportunity to develop teff-based products (Gebremariam et al., 2014). The traditional use and the potential of teff as a raw material to manufacture gluten-free products has been reviewed (Gebremariam et al., 2014). Recently, however, there is a great demand and interest to come up with new products from teff to harness its potential (Kebede et al., 2010; Wondimu and Emire, 2016; Gopirajah and Muthukumarappan, 2017; Sisay et al., 2018). Studies on the extrusion of teff to produce snacks indicated that teff extrudates are found to be denser and have limited expansion as compared to products made from rice, wheat and corn (Kebede et al., 2010; Sisay et al., 2018). However, this limitation could be improved by blending teff with cereals which have better expansion and digestibility properties (Gopirajah and Muthukumarappan, 2017; Sisay et al., 2018).

Rice (Oryza sativa, Linn.) is one the most important 
cereal feeding greater size of the population worldwide and sources of income for $f$ millions of people (Hagenimana et al., 2006; Dalbhagat et al., 2019). It is non-allergic, gluten-free source of carbohydrate, vitamins and minerals with a low fat (Dziezak, 1991). Recently, rice has become an attractive raw material for the manufacture of new cereal food including puffed/ crisp rice breakfast cereals, cakes, cookies, snacks, crackers, baby food and pre-cooked baby cereals (Ding et al., 2005; Lei et al., 2005; Suksomboon et al., 2011; Awolu et al., 2015).

Attributes like the bland taste, white color, hypoallergenicity and ease of digestion made rice flour a suitable raw material in the extrusion industry (Kadan et al., 2003; Liu et al., 2011; Dalbhagat et al., 2019). The high starch content made rice a good expanding material and suitable for extrusion cooking to develop a variety of food products (Ibanoglu et al., 2005; Dalbhagat et al., 2019). Because of its many functions as well as nutritional properties, rice could compensate for the limitations of teff in extrusion cooking of different food products.

The objectives of this study were to investigate the influence of the main extrusion operating conditions (barrel temperature and feed moisture content) and teff-to -rice ratio on selected physical, chemical and sensory properties of teff-rice blend extruded products and optimize the extrusion operating condition for optimized product quality.

\section{Materials and methods}

\subsection{Experimental materials}

Teff (Eragrostis teff [Zucc.] Trotter) and Rice (Oryza sativa, Linn.) grain of variety Cross-37 and X-Jigina, respectively obtained from Adet Agricultural Research Center (AARC) were used. These varieties were selected based on production yield and popularity.

\subsection{Raw material preparation}

Prior to extrusion, teff and rice grains were cleaned and milled into flour using small-scale commercial mill followed by sifting through $710 \mu \mathrm{m}$ mesh sieves (Kebede et al., 2010). Finally, teff and rice flour were weighed and blended with different ratios for the experiment.

\subsection{Determination of raw material composition}

The moisture content of the flour was determined according to AOAC (1995). Representative flour sample was weighed and dried at $100^{\circ} \mathrm{C}$ for $6 \mathrm{hrs}$ and cooled to room temperature and weighed. The moisture content of flour was then calculated. The amount of crude protein in the flour was determined according to AOAC (1995), by Kjeldahl method. The crude fat was determined by soxhlet extraction method (AOAC 1995), method 92085. The total ash content of flour was determined by gravimetric method according to AOAC (1995). The crude fiber was analyzed according to AOAC (1995). Total carbohydrate was determined by subtracting the sum of the other constituents from 100.

\subsection{Extrusion process}

Extrusion was performed on a pilot-scale co-rotating twin-screw food extruder (model Clextral, BC-21 $\mathrm{N}^{\mathrm{o}}$ 124, Firminy, France). A twin-screw volumetric feeder (type KMV-KT20) conveyed the flour to the extruder. A positive displacement pump (DKM-Clextral) injected water into the extruder. The extruded products were cooled for 30 mins at ambient temperature before measuring the physical properties (Ibanoglu et al., 2005). Sealed samples were stored at room temperature and physicochemical property determinations and sensory quality evaluation were carried out.

\subsection{Determination of product properties}

\subsubsection{Specific length $(\mathrm{cm} / \mathrm{g})$}

Length of extruded samples was measured by a steel tape of $1 \mathrm{~mm}$ accuracy. A vernier caliper (СДЕЈАНН, Russia) having $0.05 \mathrm{~mm}$ accuracy was used to measure the diameter of the extrudates. The weight was measured by a sensitive balance (ADAM, AFP 1200, South Africa) of $0.01 \mathrm{~g}$ sensitivity. The specific length of extrudates was determined by dividing length $(\mathrm{cm})$ by the weight of the extrudate $(\mathrm{g})$.

\subsubsection{Degree of expansion (radial expansion) and bulk density}

The expansion ratio (ER) was calculated by dividing the diameter of extrudate by the diameter of the die hole (Mason and Hoseney, 1986). Bulk density (BD) of the individual dry, cylindrical extrudate was calculated by dividing the mass of extrudate by its volume. The length of the extrudate times its average cross-sectional area gives its volume (Mason and Hoseney, 1986; Ali et al., 1996).

\subsubsection{Texture/hardness}

The cylindrical sample of extrudates were individually placed on the sample platform of a texture analyzer (LLOYD, 33773, instrument Ltd., UK) and compressed with a flat die. The breaking force in Newton of each extrudate was recorded. 


\subsubsection{Water absorption index and water solubility} index

Water absorption index (WAI) of the extruded product was determined according to Anderson et al. (1969). Sample of the extruded product $(1.25 \mathrm{~g})$ was suspended in $15 \mathrm{~mL}$ distilled water and incubated at $25^{\circ}$ $\mathrm{C}$ for $30 \mathrm{mins}$ in a water bath and centrifuged at $3000 \mathrm{x} g$ for 5 mins. The clear supernatant was decanted. The WAI was computed as grams of adsorbed water per gram of dry sample mass. The supernatant preserved from WAI measurement was evaporated at $105^{\circ} \mathrm{C}$ overnight and weighed. The water solubility index (WSI) was computed by dividing dry residue by the original sample mass.

\subsection{Sensory evaluation}

Extrudates were selected based on their fitness for sensory analysis and evaluated by 30 untrained panelists. Quality attributes of 13 selected extrudates evaluated were texture (crispness), flavor, color and overall acceptability. For overall acceptability on a 9-point hedonic scale (from $1=$ extreme dislike to $9=$ extreme like), for color and flavor a 7 point hedonic scale (from 1 $=$ extreme dislike to $7=$ extreme like) and for crispness in a 5 -point scale $(1=$ not crispy, $2=$ less crispy, $3=$ just crispy, $4=$ moderate crispy and $5=$ very crispy). The evaluation was conducted at room temperature. Orientation was given to panelists about the procedure of sensory evaluation of products and the quality attributes before conducting the test.

\subsection{Experimental design}

A $4^{1} \times 3^{2}$ factorial design was used to study the effect of barrel temperature, blend ratio and feed moisture content on physicochemical properties and sensory attributes of the extrudates. After preliminary test being carried out, values of extrusion temperature and feed moisture content were set. Products were extruded using operating conditions, 130,140 and $150^{\circ} \mathrm{C}$ barrel temperatures and 21,23 and $25 \%$ feed moisture content. The blending ratios used were $25 / 75,50 / 50$ and $75 / 25$ teff-rice ratio. Teff $(100 \%)$ was used as a control. Screw speed was fixed to be $131 \mathrm{rpm}$ from preliminary trials.

\subsection{Data analysis}

The experiment was designed and data was analyzed using Design Expert version 7 (Stat Ease, USA) response surface model was used to develop the relationship between response variables and extrusion conditions using the response surface equation below

$Y=\beta_{0}+\sum_{i=1}^{n} \beta_{i} X_{i}+\sum_{i=1}^{n} \beta_{i i} X_{i}{ }^{2}+\sum_{i<j}^{n} \sum_{j}^{n} \beta_{i j} X_{i} X_{j}+\sum_{i}^{n} \sum_{j}^{n} \sum_{k}^{n} \beta_{i j k} X_{i} X_{j} X_{k}+e$

\subsection{Optimization}

The optimal region for the best product was found by superimposing the contour plots for the different quality attributes and coming up with an overlay plot. Numerical optimization was also carried out using the desirability function approach. This was done by converting individual responses $y_{i}$ into desirability function $d_{i}$ that varies over the range 0 to 1 (Montgomery 2001). Then, for $q$ responses, the experimental variables are chosen to maximize the overall desirability D.

$$
D=\left(d_{1} \times d_{2} \times d_{3} \cdots d_{m}\right)^{\frac{1}{q}}
$$

\section{Results and discussion}

\subsection{Composition of teff and rice flour}

The moisture content, crude protein, ash, crude fiber, crude fat and total carbohydrate of teff flour was found to be $12.3,10.21,2.0,2.48,3.0$ and $70.01 \%$, respectively whereas for rice was $12.66,9.00,0.63,1.93,0.80$ and $74.98 \%$, respectively. Teff has a slightly higher protein content compared to rice. The fat, ash and fiber contents are found to be higher in teff compared to rice. These values are comparable to earlier reported values of 10.69 to $13.3 \%$ protein, 2.38 to $3.6 \%$ fat, 2.49 to $2.6 \%$ ash (Bultosa and Taylor, 2004; Kebede, 2006; Robin et al., 2015; Zhu, 2018). Compared to other cereals, teff has higher protein content than maize, sorghum, barley, millet and almost equivalent to wheat (Asrat and Frew, 2001; Bultosa and Taylor, 2004; Gebremariam et al., 2011; Zhu, 2018). The fat content of teff was found to be lower than maize $(4.6 \%)$ but higher than wheat, barley and millet and equivalent to sorghum (2.8\%) (Asrat and Frew, 2001). Rice has protein and carbohydrate content of $9.2 \%$ and $76.4 \%$, respectively (Ressureccion et al., (1997).

\subsection{Effect of extrusion conditions on extrudate quality attributes}

\subsubsection{Expansion ratio}

The results of the expansion ratio (ER) for the various samples are presented in Table 1 . The extrusion operating conditions and the blending ratio had significantly $(\mathrm{p}<0.05)$ influenced ER of extrudates. The maximum ER was $2.1 \mathrm{~cm} / \mathrm{cm}$ for samples extruded at $150^{\circ} \mathrm{C}, 23 \%$ and $21 \%$ moisture content and with $25: 75$ teff-to-rice ratio whereas the minimum ER was 1.23 for samples extruded at $130^{\circ} \mathrm{C}, 25 \%$ moisture content and 50:50\% teff-to-rice ratio. These values are comparable with rice-based, teff-based and other extrudates (Suksomboon et al., 2001; Ding et al., 2005; Wondimu and Emire, 2011). The response surface of ER as a function of extrusion condition is presented in Figure 1a. Increase in barrel temperature and a decrease in moisture 
Table 1. Effect of combinations of operating conditions on extrudates quality attributes

\begin{tabular}{|c|c|c|c|c|c|c|c|c|c|}
\hline \multirow[b]{2}{*}{ Treatment } & \multicolumn{3}{|c|}{ Processing conditions } & \multicolumn{6}{|c|}{ Product physical property } \\
\hline & $\begin{array}{c}\mathrm{R} \\
(\%)\end{array}$ & $\begin{array}{l}\text { M.C } \\
(\%)\end{array}$ & $\begin{array}{l}\mathrm{BT} \\
\left({ }^{\circ} \mathrm{C}\right)\end{array}$ & $\mathrm{ER}(\mathrm{cm} / \mathrm{cm})$ & $\mathrm{SL}(\mathrm{cm} / \mathrm{g})$ & $\mathrm{BD}\left(\mathrm{g} / \mathrm{cm}^{3}\right)$ & Texture $(\mathrm{N})$ & WAI & WSI \\
\hline 1 & $25 \mathrm{t} / 75 \mathrm{r}$ & 21 & 130 & $1.77 \pm 0.03^{\text {defg }}$ & $1.52 \pm 0.05^{\text {cdefg }}$ & $0.181 \pm 0.01^{\text {uv }}$ & $70.8 \pm 15.35^{1 \mathrm{mn}}$ & $5.0 \pm 0.6^{\mathrm{f}}$ & $0.030 \pm 0.005^{1}$ \\
\hline 2 & $25 \mathrm{t} / 75 \mathrm{r}$ & 21 & 140 & $2.03 \pm 0.04^{\mathrm{ab}}$ & $1.24 \pm 0.03^{\mathrm{jkl}}$ & $0.177 \pm 0.02^{\mathrm{v}}$ & $63.12 \pm 17.91^{\mathrm{mn}}$ & $5.5 \pm 0.5^{\mathrm{b}}$ & $0.031 \pm 0.005^{\mathrm{jkl}}$ \\
\hline 3 & $25 \mathrm{t} / 75 \mathrm{r}$ & 21 & 150 & $2.1 \pm 0.04^{\mathrm{a}}$ & $1.46 \pm 0.15^{\mathrm{gh}}$ & $0.152 \pm 0.05^{\mathrm{w}}$ & $61.01 \pm 12.34^{\mathrm{n}}$ & $5.86 \pm 0.34^{\mathrm{bc}}$ & $0.031 \pm 0.005^{\mathrm{jkl}}$ \\
\hline 4 & $25 \mathrm{t} / 75 \mathrm{r}$ & 23 & 130 & $1.7 \pm 0.05^{\mathrm{fgh}}$ & $1.27 \pm 0.28^{\mathrm{ijk}}$ & $0.193 \pm 0.04^{\text {stu }}$ & $96.53 \pm 14.39^{\text {ghijkl }}$ & $5.74 \pm 0.56^{\mathrm{c}}$ & $0.031 \pm 0.004^{\mathrm{jkl}}$ \\
\hline 5 & $25 \mathrm{t} / 75 \mathrm{r}$ & 23 & 140 & $1.83 \pm 0.03^{\text {cdef }}$ & $1.24 \pm 0.03^{\mathrm{jkl}}$ & $0.183 \pm 0.06^{\mathrm{uv}}$ & $81.22 \pm 16.78^{\mathrm{jklmn}}$ & $5.93 \pm 0.29^{\mathrm{b}}$ & $0.031 \pm 0.003^{\mathrm{jkl}}$ \\
\hline 6 & $25 \mathrm{t} / 75 \mathrm{r}$ & 23 & 150 & $2.1 \pm 0.05^{\mathrm{a}}$ & $1.46 \pm 0.05^{\mathrm{fgh}}$ & $0.162 \pm 0.04^{\mathrm{w}}$ & $76.67 \pm 15.56^{\mathrm{klmn}}$ & $6.34 \pm 0.45^{\mathrm{a}}$ & $0.031 \pm 0.005^{\mathrm{jkl}}$ \\
\hline 7 & $25 \mathrm{t} / 75 \mathrm{r}$ & 25 & 130 & $1.4 \pm 0.04^{\mathrm{kl}}$ & $1.76 \pm 0.11^{\mathrm{b}}$ & $0.196 \pm 0.04^{\mathrm{rst}}$ & $111.3 \pm 7.34^{\text {efghi }}$ & $5.983 \pm 0.5^{\mathrm{b}}$ & $0.028 \pm 0.002^{\mathrm{m}}$ \\
\hline 8 & $25 \mathrm{t} / 75 \mathrm{r}$ & 25 & 140 & $1.4 \pm 0.02^{\mathrm{kl}}$ & $1.56 \pm 0.15^{\mathrm{cd}}$ & $0.192 \pm 0.03^{\text {stu }}$ & $108.68 \pm 20.89^{\text {fghij }}$ & $6.053 \pm 0.8^{\mathrm{b}}$ & $0.028 \pm 0.003^{\mathrm{m}}$ \\
\hline 9 & $25 \mathrm{t} / 75 \mathrm{r}$ & 25 & 150 & $1.6 \pm 0.03^{\mathrm{hij}}$ & $1.48 \pm 0.06^{\text {defgh }}$ & $0.186 \pm 0.02^{\text {tuv }}$ & $91.59 \pm 19.56^{\mathrm{hijk} l}$ & $6.39 \pm 0.4^{\mathrm{a}}$ & $0.028 \pm 0.003^{\mathrm{m}}$ \\
\hline 10 & $50 \mathrm{t} / 50 \mathrm{r}$ & 21 & 130 & $1.47 \pm 0.02^{\mathrm{jkl}}$ & $1.59 \pm 0.23^{\mathrm{c}}$ & $0.214 \pm 0.03^{\mathrm{p}}$ & $94.71 \pm 15.78^{\text {ghijkl }}$ & $4.78 \pm 0.56^{\mathrm{gh}}$ & $0.033 \pm 0.005^{\mathrm{j}}$ \\
\hline 11 & $50 \mathrm{t} / 50 \mathrm{r}$ & 21 & 140 & $1.87 \pm 0.04^{\text {cde }}$ & $1.27 \pm 0.06^{\mathrm{ijk}}$ & $0.198 \pm 0.05^{\text {rst }}$ & $71.47 \pm 18.23^{1 \mathrm{mn}}$ & $4.866 \pm 0.4^{\mathrm{fgh}}$ & $0.034 \pm 0.004^{\mathrm{i}}$ \\
\hline 12 & $50 \mathrm{t} / 50 \mathrm{r}$ & 21 & 150 & $2.03 \pm 0.05^{\mathrm{ab}}$ & $1.32 \pm 0.05^{\mathrm{ij}}$ & $0.193 \pm 0.05^{\text {stu }}$ & $60.23 \pm 7.42^{\mathrm{n}}$ & $5.37 \pm 0.38^{\mathrm{de}}$ & $0.035 \pm 0.003^{\mathrm{hi}}$ \\
\hline 13 & $50 \mathrm{t} / 50 \mathrm{r}$ & 23 & 130 & $1.6 \pm 0.04^{\mathrm{hij}}$ & $2.03 \pm 0.02^{\mathrm{a}}$ & $0.212 \pm 0.01^{\mathrm{pq}}$ & $127.21 \pm 20.67^{\mathrm{def}}$ & $5.323 \pm 0.27^{\mathrm{de}}$ & $0.031 \pm 0.004^{\mathrm{jkl}}$ \\
\hline 14 & $50 \mathrm{t} / 50 \mathrm{r}$ & 23 & 140 & $1.77 \pm 0.04^{\mathrm{defg}}$ & $1.35 \pm 0.03^{\mathrm{i}}$ & $0.206 \pm 0.03^{\mathrm{pqr}}$ & $90.39 \pm 11.87^{\mathrm{hijklm}}$ & $5.357 \pm 0.56^{\mathrm{de}}$ & $0.031 \pm 0.005^{\mathrm{jkl}}$ \\
\hline 15 & $50 \mathrm{t} / 50 \mathrm{r}$ & 23 & 150 & $1.93 \pm 0.05^{\mathrm{bc}}$ & $1.54 \pm 0.03^{\text {cdef }}$ & $0.201 \pm 0.03^{\mathrm{qrs}}$ & $72.781 \pm 15.67^{\mathrm{mn}}$ & $5.403 \pm 0.93^{\mathrm{de}}$ & $0.033 \pm 0.001^{j}$ \\
\hline 16 & $50 \mathrm{t} / 50 \mathrm{r}$ & 25 & 130 & $1.23 \pm 0.04^{\mathrm{m}}$ & $1.81 \pm 0.05^{\mathrm{b}}$ & $0.25 \pm 0.02^{\ln }$ & $120.42 \pm 13.45^{\text {defg }}$ & $5.42 \pm 0.65^{\mathrm{de}}$ & $0.031 \pm 0.004^{\mathrm{kl}}$ \\
\hline 17 & $50 \mathrm{t} / 50 \mathrm{r}$ & 25 & 140 & $1.67 \pm 0.02^{\mathrm{gh}}$ & $1.56 \pm 0.06^{\mathrm{cde}}$ & $0.244 \pm 0.06^{\mathrm{no}}$ & $102.32 \pm 10.56^{\text {fohijk }}$ & $5.26 \pm 0.6^{\mathrm{e}}$ & $0.03 \pm 0.006^{\mathrm{jkl}}$ \\
\hline 18 & $50 \mathrm{t} / 50 \mathrm{r}$ & 25 & 150 & $1.90 \pm 0.05^{\mathrm{bcd}}$ & $1.74 \pm 0.11^{\mathrm{b}}$ & $0.234 \pm 0.06^{\circ}$ & $70.15 \pm 18.37^{\mathrm{lmn}}$ & $5.703 \pm 0.6^{\mathrm{c}}$ & $0.032 \pm 0.002^{\mathrm{jk}}$ \\
\hline 19 & $75 \mathrm{t} / 25 \mathrm{r}$ & 21 & 130 & $1.43 \pm 0.03^{\mathrm{kl}}$ & $1.49 \pm 0.05^{\text {defgh }}$ & $0.289 \pm 0.041$ & $126.1 \pm 17.87^{\mathrm{def}}$ & $3.153 \pm 0.59^{\mathrm{p}}$ & $0.037 \pm 0.003^{\mathrm{fg}}$ \\
\hline 20 & $75 \mathrm{t} / 25 \mathrm{r}$ & 21 & 140 & $1.83 \pm 0.04^{\text {cdef }}$ & $0.99 \pm 0.11^{\mathrm{p}}$ & $0.268 \pm 0.03^{\mathrm{m}}$ & $117.26 \pm 13.29^{\text {efgh }}$ & $3.96 \pm 0.60^{\mathrm{k}}$ & $0.038 \pm 0.003^{\text {ef }}$ \\
\hline 21 & $75 \mathrm{t} / 25 \mathrm{r}$ & 21 & 150 & $1.9 \pm 0.03^{\mathrm{cd}}$ & $1.23 \pm 0.10^{\mathrm{kl}}$ & $0.265 \pm 0.03^{\mathrm{m}}$ & $83.33 \pm 10.89^{\mathrm{ijklmn}}$ & $4.44 \pm 0.58^{\mathrm{j}}$ & $0.039 \pm 0.003^{\mathrm{e}}$ \\
\hline 22 & $75 \mathrm{t} / 25 \mathrm{r}$ & 23 & 130 & $1.63 \pm 0.06^{\mathrm{ghi}}$ & $1.16 \pm 0.04^{\operatorname{lmno}}$ & $0.332 \pm 0.05^{\mathrm{k}}$ & $116.56 \pm 8.95^{\mathrm{efgh}}$ & $4.68 \pm 0.34^{\mathrm{hi}}$ & $0.035 \pm 0.004^{\mathrm{hi}}$ \\
\hline 23 & $75 \mathrm{t} / 25 \mathrm{r}$ & 23 & 140 & $1.73 \pm 0.05^{\mathrm{efgh}}$ & $1.22 \pm 0.05^{\mathrm{klm}}$ & $0.323 \pm 0.06^{\mathrm{k}}$ & $103.32 \pm 12.78^{\text {fghijk }}$ & $4.783 \pm 0.5^{\mathrm{gh}}$ & $0.036 \pm 0.002^{\text {ghi }}$ \\
\hline 24 & $75 \mathrm{t} / 25 \mathrm{r}$ & 23 & 150 & $1.87 \pm 0.023^{\text {cde }}$ & $1.43 \pm 0.01^{\mathrm{h}}$ & $0.293 \pm 0.10^{1}$ & $96.61 \pm 17.35^{\text {ghijkl }}$ & $4.53 \pm 0.5^{\mathrm{ij}}$ & $0.035 \pm 0.003^{\mathrm{gh}}$ \\
\hline 25 & $75 \mathrm{t} / 25 \mathrm{r}$ & 25 & 130 & $1.60 \pm 0.03^{\mathrm{hij}}$ & $1.13 \pm 0.05^{\text {no }}$ & $0.393 \pm 0.15^{\mathrm{h}}$ & $98.08 \pm 15.30^{\text {ghijkl }}$ & $4.427 \pm 0.45^{\mathrm{j}}$ & $0.033 \pm 0.005^{\mathrm{j}}$ \\
\hline 26 & $75 \mathrm{t} / 25 \mathrm{r}$ & 25 & 140 & $1.70 \pm 0.04^{\text {fgh }}$ & $1.09 \pm 0.11^{\circ}$ & $0.378 \pm 0.11^{\mathrm{i}}$ & $97.15 \pm 7.21^{\text {ghijkl }}$ & $4.583 \pm 0.48^{\mathrm{ij}}$ & $0.0346 \pm 0.005^{\mathrm{h}}$ \\
\hline 27 & $75 \mathrm{t} / 25 \mathrm{r}$ & 25 & 150 & $1.83 \pm 0.05^{\mathrm{cdef}}$ & $1.11 \pm 0.05^{\circ}$ & $0.356 \pm 0.13^{\mathrm{j}}$ & $91.48 \pm 9.45^{\mathrm{hijkl}}$ & $4.93 \pm 0.8^{\mathrm{fg}}$ & $0.035 \pm 0.006^{\mathrm{ghi}}$ \\
\hline 28 & $100 \mathrm{t}$ & 21 & 130 & $1.63 \pm 0.05^{\mathrm{ghi}}$ & $1.74 \pm 0.04^{\mathrm{b}}$ & $0.414 \pm 0.06^{\mathrm{ef}}$ & $167.93 \pm 20.23^{\mathrm{b}}$ & $3.45 \pm 0.68^{\circ}$ & $0.045 \pm 0.004^{\mathrm{c}}$ \\
\hline 29 & $100 \mathrm{t}$ & 21 & 140 & $1.77 \pm 0.05^{\mathrm{defg}}$ & $1.25 \pm 0.04^{\mathrm{jk}}$ & $0.408 \pm 0.06^{\mathrm{fg}}$ & $160.03 \pm 16.78^{\mathrm{bc}}$ & $3.58 \pm 0.29^{\mathrm{no}}$ & $0.046 \pm 0.003^{\mathrm{ab}}$ \\
\hline 30 & $100 \mathrm{t}$ & 21 & 150 & $1.87 \pm 0.04^{\text {cde }}$ & $1.47 \pm 0.011^{\mathrm{fgh}}$ & $0.401 \pm 0.05^{\text {gh }}$ & $165.58 \pm 18.53^{\mathrm{b}}$ & $3.587 \pm 0.40^{\mathrm{mno}}$ & $0.048 \pm 0.003^{\mathrm{a}}$ \\
\hline 31 & $100 \mathrm{t}$ & 23 & 130 & $1.33 \pm 0.02^{\mathrm{lm}}$ & $1.58 \pm 0.06^{\mathrm{c}}$ & $0.426 \pm 0.02^{\mathrm{cd}}$ & $146.57 \pm 14.32^{\mathrm{bc}}$ & $3.527 \pm 0.38^{\circ}$ & $0.045 \pm 0.002^{\mathrm{bc}}$ \\
\hline 32 & $100 \mathrm{t}$ & 23 & 140 & $1.47 \pm 0.03^{\mathrm{jkl}}$ & $1.32 \pm 0.05^{\mathrm{ij}}$ & $0.42 \pm 0.12^{\mathrm{de}}$ & $136.61 \pm 17.23^{\mathrm{cde}}$ & $3.623 \pm 0.67^{\mathrm{mno}}$ & $0.047 \pm 0.003^{\mathrm{a}}$ \\
\hline 33 & $100 \mathrm{t}$ & 23 & 150 & $1.67 \pm 0.03^{\mathrm{gh}}$ & $1.48 \pm 0.04^{\mathrm{efgh}}$ & $0.414 \pm 0.10^{\mathrm{ef}}$ & $122.23 \pm 8.69^{\mathrm{defg}}$ & $3.761 \pm 0.46^{\mathrm{mn}}$ & $0.048 \pm 0.003^{\mathrm{a}}$ \\
\hline 34 & $100 \mathrm{t}$ & 25 & 130 & $1.4 \pm 0.05^{\mathrm{kl}}$ & $1.20 \pm 0.03^{\mathrm{klmn}}$ & $0.473 \pm 0.15^{\mathrm{a}}$ & $227.1 \pm 13.09^{\mathrm{a}}$ & $3.537 \pm 0.6^{\circ}$ & $0.041 \pm 0.004^{\mathrm{d}}$ \\
\hline 35 & $100 \mathrm{t}$ & 25 & 140 & $1.430 .04^{\mathrm{kl}}$ & $1.32 \pm 0.03^{\mathrm{ij}}$ & $0.454 \pm 0.05^{\mathrm{b}}$ & $168.27 \pm 10.35^{\mathrm{b}}$ & $3.78 \pm 0.5^{\mathrm{klm}}$ & $0.044 \pm 0.002^{\mathrm{c}}$ \\
\hline 36 & $100 \mathrm{t}$ & 25 & 150 & $1.50 \pm 0.05^{\mathrm{ijk}}$ & $1.14 \pm 0.03^{\mathrm{mno}}$ & $0.436 \pm 0.04^{\mathrm{c}}$ & $156.95 \pm 6.56^{\mathrm{bc}}$ & $3.933 \pm 0.49^{\mathrm{kl}}$ & $0.045 \pm 0.005^{\mathrm{c}}$ \\
\hline
\end{tabular}

Values are expressed as mean \pm standard deviation. Values with the same letter in a column are not significantly different $(\mathrm{p}>0.05) . \mathrm{T}=$ barrel temperature, $\mathrm{R}=$ Blend ratio, $\mathrm{M} . \mathrm{C}=$ feed moisture content, $\mathrm{ER}=$ expansion ratio, $\mathrm{SL}=$ specific length, $\mathrm{BD}$ $=$ bulk density $\mathrm{WAI}=$ water absorption index, $\mathrm{WSI}=$ water solubility index and $\mathrm{t}=$ teff and $\mathrm{r}=$ rice.

content increased the expansion ratio. Increase in the proportion of teff resulted in a decrease in ER. Similar trends were reported in previous studies of teff based extrudates (Kebede 2010; Wondimu and Emire, 2011; Gopirajah and Muthukumarappan, 2017). The degree of superheating of water in the extruder would increase at higher temperature leading to greater expansion. A decrease in ER with the increase in moisture content has also been reported for texturized rice-based and other extrudates (Moraru and Kokini, 2003; Ding et al., 2005; Liu et al., 2011). The phenomena of extrudate expansion usually are the results of extrusion at high temperature and low moisture content (Wondimu and Emire, 2011). The decrease in BD with the increase in extrusion temperature could be attributed to higher energy for the flashing off super-heated water from the extrudates as it 

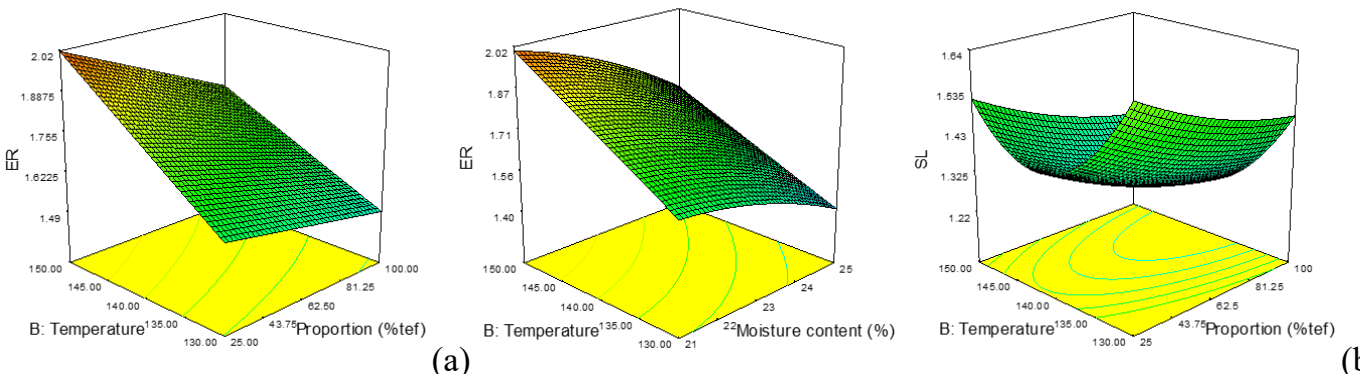

(a)
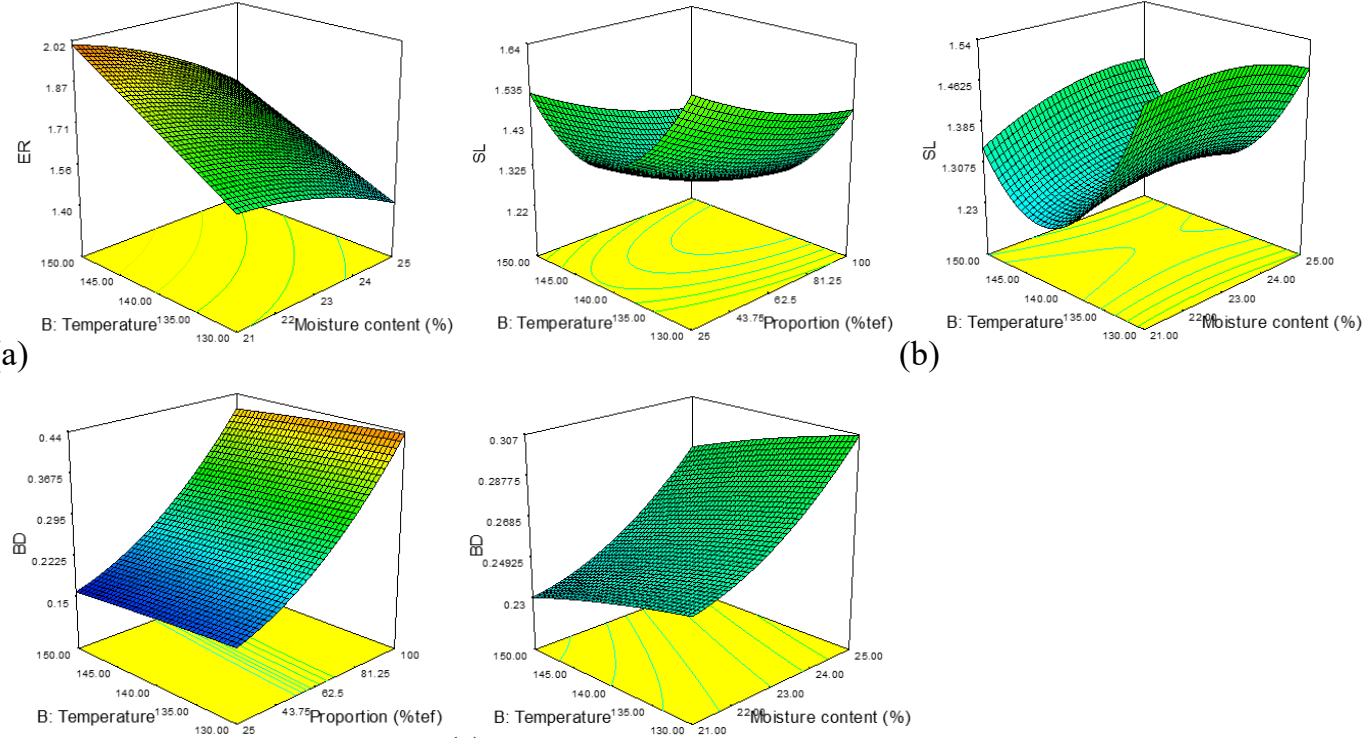

(c)

(b)

Figure 1. Response surface for Expansion ratio (ER), Specific Length (SL) and Bulk density (BD) as a function of Extrusion conditions

left the die (Singh et al., 2016).

A quadratic polynomial described the functional relationship between the extrusion operating conditions and expansion ratio $\left(\mathrm{R}^{2}=0.75\right.$ and Adjusted $\left.\mathrm{R}^{2}=0.69\right)$. The values of the model coefficients and the degree of fit are presented in Table 2. Temperature, feed moisture and blending proportion had significant $(\mathrm{p}<0.05)$ influence on the texture.

\subsubsection{Specific length}

Specific length (SL) refers to length per unit weight and is the measure of the axial expansion of extrudates. The specific length of the extruded product was found to be affected significantly $(\mathrm{p}<0.05)$ barrel temperature, blend ratio and feed moisture content. The maximum SL was found to be $2.034 \pm 0.02 \mathrm{~cm} / \mathrm{g}$ at $130^{\circ} \mathrm{C}, 23 \%$ moisture and $50 \mathrm{t} / 50 \mathrm{r} \%$ blend ratio. The minimum values were $0.986 \pm 0.11$ at $140{ }^{\circ} \mathrm{C}, 21 \%$ moisture and $75 \mathrm{t} / 25 \mathrm{r} \%$. The SL decreased with the increase in extrusion temperature from 130 to $140^{\circ} \mathrm{C}$ followed by an increase with the increase in temperature to $150^{\circ} \mathrm{C}$ (Figure 1b). A decrease in SL with the increase in extrusion temperature and decrease in screw speed was reported for corn grits (Ali et al., 1996). The more the extrudates expand in either the axial and radial direction, the less dense they become indicating a higher proportion of starch gelatinization.

\subsubsection{Bulk density}

Barrel temperature, feed moisture content and blending ration had significant $(\mathrm{p}<0.05)$ effect on the bulk density (BD) (Table 1). The maximum $\mathrm{BD}$ was $0.473 \pm 0.15 \mathrm{~g} / \mathrm{cm}^{3}$ at $130^{\circ} \mathrm{C}$ barrel temperature, $100 \%$ teff and $25 \%$ feed moisture content whereas the minimum was $0.152 \pm 0.05 \mathrm{~g} / \mathrm{cm}^{3}$ at $150^{\circ} \mathrm{C}, 21 \%$ moisture and
$25: 75 \%$ (teff-to-rice) ratio. The values obtained in this study are comparable to teff-based and rice-based extrudates reported in earlier studies (Bhattacharya and Prakash, 1994; Ding et al., 2005; Kebede 2010; Wondimu and Emire, 2011; Sisay et al., 2018). The response surface as a function of the extrusion variables is presented in Figure 1c. High extrusion temperature, rice proportion and low moisture content resulted in decreased BD. High extrusion temperature and reduced feed moisture content have been reported to reduce the bulk density of rice-based extrudates (Lei et al., 2005; Ding et al., 2005). The phenomenon was attributed to the higher gelling temperature of teff which implies that teff starch will have high stability and forms dense structure (Bultosa et al., 2002; Gopirajah and Muthukumarappan, 2017). Increase in teff proportion has been reported to increase the $\mathrm{BD}$ of teff-based extrudates. The high percentage of fat in teff compared to rice may lubricate the melt in the extruder and may reduce its degree of transformation (Robin et al., 2015). Studies suggested that high feed moisture content during extrusion causes plasticization and reduce the elasticity of the melt which in turn reduces SME and limits the expansion resulting in denser extrudates (Wondimu and Emire, 2011; Dalbhagatt et al., 2019). A quadratic response surface model described the relationship between the $\mathrm{BD}$ and extrusion variables. The degree of fit and the model coefficients are presented in Table 2. The linear terms of the extrusion variables significantly (0.05) affected the BD.

\subsubsection{Texture/hardness}

The extrusion conditions significantly $(\mathrm{p}<0.05)$ affected the force required to break the extrudates (Table 1). The force required to break a food a material indicates the relative hardness and is related to the 
Table 2. Model coefficients and degree of fit for the different quality attributes

\begin{tabular}{lcccccccccc}
\hline \multirow{2}{*}{$\begin{array}{c}\text { Model } \\
\text { Coefficients }\end{array}$} & ER & SL & BD & Texture & WAI & WSI & Flavour & Colour & Crispiness & OAC \\
\hline$\beta_{0}$ & -7.77 & 35.9 & 0.99 & 727.86 & -15.48 & -0.031 & -27.52 & 29.67 & 58.44 & -6.85 \\
$\beta_{1}(\mathrm{M})$ & 0.49 & 0.26 & -0.096 & -37.54 & 0.76 & $5.23 \mathrm{E}-03$ & 1.23 & -0.928 & 5.19 & -0.307 \\
$\beta_{2}(\mathrm{~T})$ & 0.052 & -0.55 & $4.08 \mathrm{E}-03$ & -3.15 & 0.13 & $1.87 \mathrm{E}-04$ & 0.35 & -0.13 & -1.72 & 0.201 \\
$\beta_{3}(\mathrm{R})$ & $-6.26 \mathrm{E}-03$ & 0.04 & $-2.93 \mathrm{E}-03$ & 1.17 & 0.02 & $-3.63 \mathrm{E}-04$ & -0.085 & -0.037 & 0.19 & 0.18 \\
$\beta_{12}(\mathrm{M} \times \mathrm{T})$ & $-1.25 \mathrm{E}-03$ & $1.40 \mathrm{E}-03$ & $-4.06 \mathrm{E}-05$ & -0.18 & $-4.02 \mathrm{E}-03$ & $-3.13 \mathrm{E}-06$ & -0.013 & $5.30 \mathrm{E}-03$ & 0.035 & $-1.73 \mathrm{E}-03$ \\
$\beta_{13}(\mathrm{M} \times \mathrm{R})$ & $7.45 \mathrm{E}-04$ & $-1.80 \mathrm{E}-03$ & $1.37 \mathrm{E}-04$ & -0.09 & $-1.09 \mathrm{E}-03$ & $-1.80 \mathrm{E}-06$ & $9.67 \mathrm{E}-03$ & & $-2.27 \mathrm{E}-03$ & $7.73 \mathrm{E}-03$ \\
$\beta_{23}(\mathrm{~T} \times \mathrm{R})$ & $-9.52 \mathrm{E}-05$ & $-2.00 \mathrm{E}-06$ & $-1.87 \mathrm{E}-06$ & $-4.83 \mathrm{E}-03$ & $-1.74 \mathrm{E}-04$ & $1.73 \mathrm{E}-06$ & $-1.13 \mathrm{E}-03$ & & $-6.68 \mathrm{E}-04$ & $-2.83 \mathrm{E}-03$ \\
$\beta_{11}\left(\mathrm{M}^{2}\right)$ & $-9.30 \mathrm{E}-03$ & $-7.18 \mathrm{E}-03$ & $2.31 \mathrm{E}-03$ & 1.58 & & $-1.19 \mathrm{E}-04$ & & & -0.22 & \\
$\beta_{22}\left(\mathrm{~T}^{2}\right)$ & & $1.82 \mathrm{E}-03$ & $-1.50 \mathrm{E}-05$ & 0.022 & & $-5.00 \mathrm{E}-07$ & & & $3.53 \mathrm{E}-03$ & \\
$\beta_{33}\left(\mathrm{R}^{2}\right)$ & & $1.80 \mathrm{E}-05$ & $2.75 \mathrm{E}-05$ & 0.021 & & $2.90 \mathrm{E}-06$ & & & $-6.68 \mathrm{E}-04$ & \\
$\mathrm{R}^{2}$ & 0.749 & 0.4 & 0.98 & 0.8383 & 0.947 & 0.977 & 0.702 & 0.669 & 0.991 & 0.8156 \\
$\mathrm{R}_{\text {adj }}^{2}$ & 0.6862 & 0.192 & 0.974 & 0.7823 & 0.936 & 0.969 & 0.403 & 0.503 & 0.964 & 0.6312 \\
$\mathrm{p}$-value & $<0.0001$ & 0.093 & $<0.0001$ & $<0.0001$ & $<0.0001$ & $<0.0001$ & 0.1609 & 0.044 & 0.0066 & 0.0466 \\
\hline
\end{tabular}

$\mathrm{T}=$ Temperature, $\mathrm{R}=$ teff proportion, $\mathrm{M}=$ Feed moisture

perceived crispness and crunchiness. The maximum values were $222.7 \mathrm{~N}$ for extrudates at $130^{\circ} \mathrm{C}$ barrel temperature, $25 \%$ feed moisture content and $100 \%$ teff whereas the minimum was $60.23 \mathrm{~N}$ at $150^{\circ} \mathrm{C}$ barrel temperature, $21 \%$ moisture and 50:50\% (teff-to-rice) blend ratio was less hard and required minimum force. The response surface as a function of extrusion variables is presented in Figure 2a. Increase in the proportion of teff and moisture content and reduction in extrusion temperature resulted in greater force required to break the samples. This could be due to higher protein and fiber content in teff which resulted in the reduced expansion and increased density and hardness. Such a trend was reported by previous studies on extruded products (Wondimu and Emire, 2011). This is also an indication of better expansion exhibited by rice as compared to teff. At high extrusion temperature, high starch gelatinization occurs resulting in high loss of moisture compared to low extrusion temperature. More cells are produced at high temperature (Köksel et al., 2004; Singh et al., 2016). The extrusion operating conditions and texture were related by a quadratic polynomial $\left(\mathrm{R}^{2}=0.84\right.$ and Adjusted $\left.\mathrm{R}^{2}=0.78\right)$. The values of the model coefficients and the degree of fit are presented in Table 2. Temperature, feed moisture, blending proportion and quadratic term of the blend proportion had significant $(\mathrm{p}<0.05)$ influence on the texture.

\subsubsection{Water absorption index (WAI)}

Extrusion temperature, moisture content and blend ratio significantly affected $(\mathrm{p}<0.05)$ the WAI (Table 1$)$. Maximum water absorption of $6.39 \pm 0.4$ was at $150^{\circ} \mathrm{C}$ extrusion temperature, $25 \%$ moisture content and 25:75 (teff-to-rice) blend ratio whereas the minimum value of $3.15 \pm 0.59$ was observed at $130^{\circ} \mathrm{C}, 21 \%$ and $75: 25$ (teff-to -rice) of extrusion temperature, moisture content and blend ratio, respectively. The ranges of WAI observed in this study were comparable to values reported for teffbased extrudates which were in the ranges of 0.7 to 7.89 (Wondimu and Emire, 2016; Gopirajah and Muthukumarappan, 2017; Sisay et al., 2018) and ricebased extrudates 2.1 to 7.65 (Ding et al., 2005; Suksomboon et al., 2011; Awolu et al., 2015)

The WAI is an indicator of the volume occupied by swollen starch in excess water, (Ding et al., 2005). The WAI increased with an increase in extrusion temperature, feed moisture content and proportion of rice flour. The response surface for WAI as a function of the extrusion parameters is presented in Figure $2 \mathrm{~b}$. The increase in WAI with the increase in moisture content has been reported in earlier research. The increase in WAI was attributed to the higher proportion of gelatinized starch granules and maximum WAI indicated complete gelatinization (Ding et al., 2005; Kebede, 2006; Suksomboon et al., 2011; Gbenyi et al., 2017). Increase in WAI with increase extrusion temperature has also been reported (Suksomboon et al., 2011; Singh et al., 2016). The functional relationship between the extrusion operating conditions and WAI was described by a two factor interaction $(2 \mathrm{FI})$ model $\left(\mathrm{R}^{2}=0.95\right.$ and Adjusted $\mathrm{R}^{2}=0.94$ ). The values of the model coefficients and the degree of fit are presented in Table 2.Temperature, feed moisture and blending proportion had significant $(p<0.05)$ influence on the texture.

\subsubsection{Water solubility index (WSI)}

Water solubility index (WSI) of extrudates was significantly $(p<0.05) \quad$ influenced by extrusion temperature, moisture content and blend ratio (Table 1). Increase in extrusion temperature, decrease in moisture 

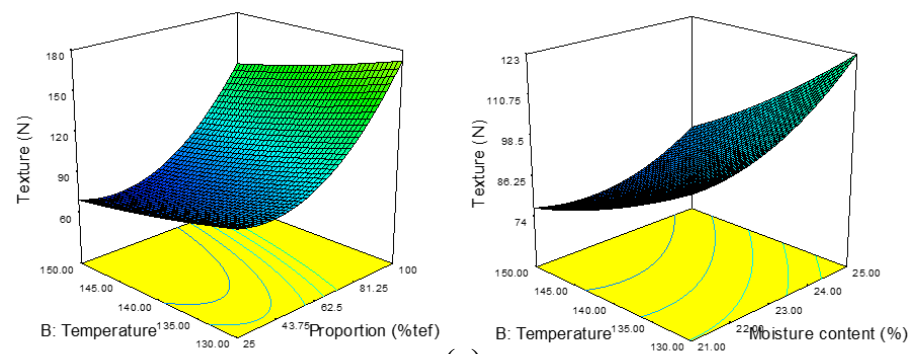

(a)
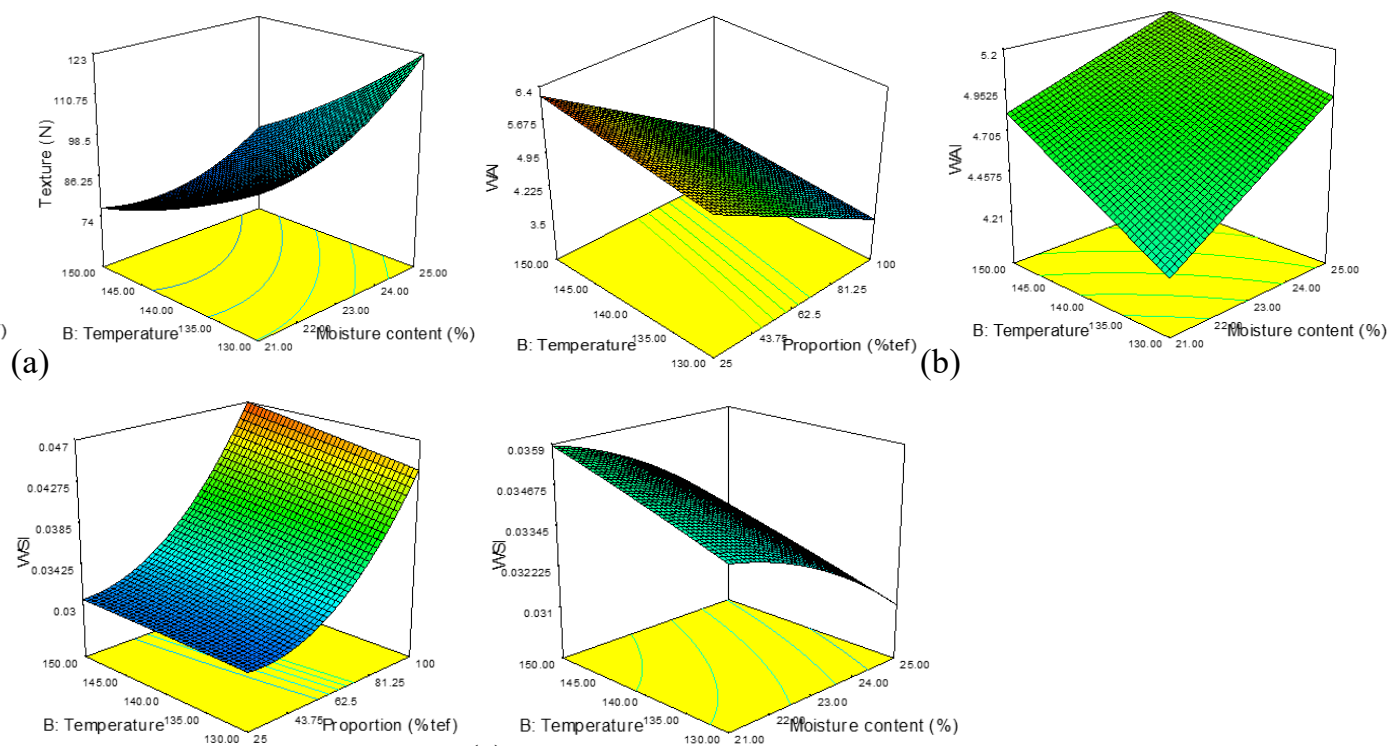

(c)

(b)

Figure 2. Response surface for Texture, Water Absorption Index (WAI) and Water solubility index (WSI) as a function of Extrusion conditions

content and increase in teff content resulted in increased WSI (Figure 2c). The maximum WSI was found to be $0.048 \pm 0.003$ at 140 and $150^{\circ} \mathrm{C}$ barrel temperature, 21 and $23 \%$ feed moisture and $100 \%$ teff. The minimum WSI was at 25\% feed moisture content and 25:75 (teff: rice ratio). WSI is an indicator of starch degradation during extrusion (Ollet et al., 1990) and extrusion causes the formation of water-soluble molecules quantified by the measurement of WSI (Robin et al., 2015). Increase in extrusion temperature and decrease in moisture content has also been reported to increase WSI (Ding et al., 2005; Lei et al., 2005; Lei, 2005; Kebede, 2010; Suksomboon et al., 2011). The increase in WSI with extrusion temperature may be attributed to the high level of starch breakdown which in turn increased the release of the soluble compound (Singh et al., 2016). Moisture content influences the mechanical energies which in turn bring a significant effect on the extent of starch gelatinization and fragmentation during extrusion (Lei et al., 2005). The increase in WSI with the increase in teff proportion indicates that extrusion resulted in more degradation in teff compared to rice. Relatively high WSI of extruded teff has been reported and differences in WSI among grains depends on a number of factors including starch and lipid contents, starch crystalline structure and particle size (Robin et al., 2015). The extrusion conditions and WSI were functionally related $\left(\mathrm{R}^{2}=0.98\right.$ and Adjusted $\left.\mathrm{R}^{2}=0.97\right)$ by a quadratic polynomial. Temperature, blend proportion, moisture content and the interaction between temperature and proportion significantly $(p<0.05)$ affected WSI. The model coefficients and the degree of fit of the model are presented in Table 2.

\subsection{Sensory quality}

Table 3 presents the sensory scores for the selected extrudates produced by the different combination of extrusion operation conditions and blend ratios. Results showed that there was significant $(\mathrm{p}<0.05)$ difference between the products due to extrusion conditions and blend ratios.

\subsubsection{Flavor}

Flavor score for the products ranged from $3.0 \pm 0.38$ to $6.1 \pm 1.07$. The minimum scores were for products with $100 \%$ teff $21 \%$ feed moisture (between "slightly dislike" and "neither like nor dislike") whereas the maximum scores were in general with a higher proportion of rice and higher barrel temperature. The result indicates that increased rice proportion brought about a better flavor score (Figure 3a).

\subsubsection{Colour}

Colour score of products had the highest value $6.7 \pm 1.40$ ("moderately like" and "like very much") for products at $25: 75 \%$ (teff-to-rice) blend ratio, $130^{\circ} \mathrm{C}$ and $21 \%$ moisture content and lowest value $2.5 \pm 0.35$ ("moderately dislike" and "slightly dislike") at $100 \%$ teff, $150^{\circ} \mathrm{C}$ and $25 \%$ feed moisture content (Table 3. In general color score increased with increase in the proportion of rice (Figure 3b). This could be attributed to the bright color imparted due to the white color of rice flour that has contributed to an appealing appearance. The relationship between the extrusion operating conditions and color was described by a two factor interaction $(2 \mathrm{FI})$ model $\left(\mathrm{R}^{2}=0.0 .67\right.$ and Adjusted $\mathrm{R}^{2}=$ $0.50)$. The values of the model coefficients and the degree of fit are presented in Table 2. Blend proportion had the most significant $(p<0.05)$ effect.

\subsubsection{Crispiness}


Table 3. Sensory evaluation of extruded teff and rice flour products

\begin{tabular}{cccccccc}
\hline \multirow{2}{*}{ Treatment } & \multicolumn{3}{c}{ Processing conditions } & \multicolumn{4}{c}{ Product sensory quality } \\
\cline { 2 - 8 } & R (\%) & M.C $(\%)$ & $\mathrm{T}\left({ }^{\circ} \mathrm{C}\right)$ & Flavour* & Color* & Crispiness* & Overall acceptance* \\
\hline 1 & $25 \mathrm{t} / 75 \mathrm{r}$ & 21 & 130 & $6.0 \pm 1.68^{\mathrm{ab}}$ & $6.7 \pm 1.40^{\mathrm{a}}$ & $4.6 \pm 1.26^{\mathrm{ab}}$ & $7.4 \pm 1.76^{\mathrm{b}}$ \\
2 & $25 \mathrm{t} / 75 \mathrm{r}$ & 21 & 140 & $5.6 \pm 1.60^{\mathrm{c}}$ & $6.6 \pm 1.23^{\mathrm{a}}$ & $4.2 \pm 1.60^{\mathrm{d}}$ & $7.7 \pm 1.34^{\mathrm{a}}$ \\
3 & $25 \mathrm{t} / 75 \mathrm{r}$ & 23 & 130 & $5.6 \pm 1.48^{\mathrm{c}}$ & $6.5 \pm 1.41^{\mathrm{a}}$ & $4.6 \pm 1.18^{\mathrm{ab}}$ & $6.8 \pm 1.62^{\mathrm{c}}$ \\
4 & $50 \mathrm{t} / 50 \mathrm{r}$ & 21 & 130 & $6.0 \pm 1.88^{\mathrm{ab}}$ & $5.4 \pm 1.60^{\mathrm{bc}}$ & $4.5 \pm 1.64^{\mathrm{bc}}$ & $7.3 \pm 1.28^{\mathrm{b}}$ \\
5 & $50 \mathrm{t} / 50 \mathrm{r}$ & 21 & 150 & $6.0 \pm 2.03^{\mathrm{ab}}$ & $5.2 \pm 1.18^{\mathrm{c}}$ & $4.4 \pm 1.38^{\mathrm{c}}$ & $7.6 \pm 1.40^{\mathrm{a}}$ \\
6 & $50 \mathrm{t} / 50 \mathrm{r}$ & 23 & 130 & $5.2 \pm 1.44^{\mathrm{d}}$ & $2.9 \pm 0.35^{\mathrm{f}}$ & $4.7 \pm 1.29^{\mathrm{a}}$ & $5.6 \pm 1.52^{\mathrm{e}}$ \\
7 & $50 \mathrm{t} / 50 \mathrm{r}$ & 25 & 130 & $5.0 \pm 1.28^{\mathrm{bc}}$ & $5.3 \pm 1.26^{\mathrm{c}}$ & $2.9 \pm 0.45^{\mathrm{f}}$ & $6.5 \pm 1.60^{\mathrm{d}}$ \\
8 & $75 \mathrm{t} / 25 \mathrm{r}$ & 21 & 130 & $5.7 \pm 1.78^{\mathrm{c}}$ & $5.3 \pm 1.42^{\mathrm{c}}$ & $4.4 \pm 1.73^{\mathrm{c}}$ & $7.6 \pm 1.82^{\mathrm{a}}$ \\
9 & $75 \mathrm{t} / 50 \mathrm{r}$ & 23 & 140 & $6.1 \pm 1.07^{\mathrm{a}}$ & $5.6 \pm 1.98^{\mathrm{b}}$ & $4.0 \pm 1.02^{\mathrm{e}}$ & $6.8 \pm 2.03^{\mathrm{c}}$ \\
10 & $100 \mathrm{t}$ & 21 & 130 & $3.0 \pm 0.93^{\mathrm{f}}$ & $4.0 \pm 0.60^{\mathrm{d}}$ & $2.6 \pm 0.36^{\mathrm{g}}$ & $4.6 \pm 1.23^{\mathrm{f}}$ \\
11 & $100 \mathrm{t}$ & 21 & 140 & $3.2 \pm 0.45^{\mathrm{ef}}$ & $3.4 \pm 0.22^{\mathrm{e}}$ & $1.8 \pm 0.24^{\mathrm{i}}$ & $4.1 \pm 1.40^{\mathrm{g}}$ \\
12 & $100 \mathrm{t}$ & 21 & 150 & $3.0 \pm 0.38^{\mathrm{f}}$ & $3.1 \pm 0.41^{\mathrm{f}}$ & $1.7 \pm 0.20^{\mathrm{i}}$ & $3.2 \pm 0.89^{\mathrm{i}}$ \\
13 & $100 \mathrm{t}$ & 25 & 150 & $3.4 \pm 0.76^{\mathrm{e}}$ & $2.5 \pm 0.35^{\mathrm{g}}$ & $2.2 \pm 0.28^{\mathrm{h}}$ & $3.8 \pm 0.52^{\mathrm{h}}$ \\
\hline
\end{tabular}

Values are expressed as mean \pm standard deviation. Values with the same letter in a column are not significantly different $(\mathrm{p}>0.05) . \mathrm{T}=$ barrel temperature, $\mathrm{R}=$ blend ratio, $\mathrm{M} . \mathrm{C}=$ feed moisture content, $\mathrm{t}=$ teff and $\mathrm{r}=$ rice.
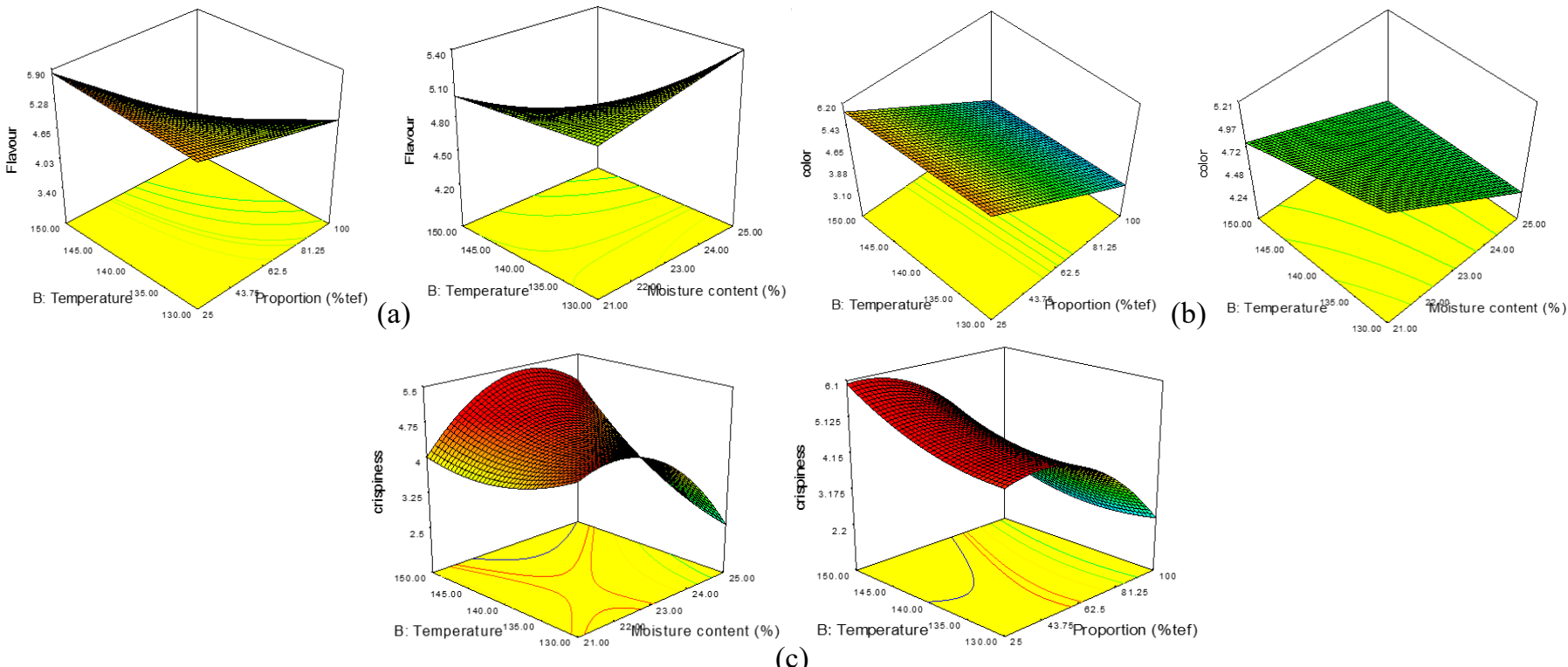

(c)

Figure 3. Response surface for flavour, Color and Crispiness as a function of Extrusion conditions

The crispiness score of extrudates is presented in Table 3. The maximum crispiness score was $4.7 \pm 1.29$ (between "moderately crispy" to "very crispy") at $130^{\circ} \mathrm{C}$ temperature, $50 \mathrm{t} / 50 \mathrm{r} \%$ blend ratio and $23 \%$ feed moisture content whereas the minimum was $1.7 \pm 0.20$ (between "not crispy" and "less crispy") at $150^{\circ} \mathrm{C}$ barrel temperature, $21 \%$ feed moisture and $100 \%$ teff. In general products with a higher proportion of rice exhibited higher crispiness score (Figure 3c) which was also related low texture (force required to break the samples and low bulk density. Crispiness score increased with increase in moisture content up to about $23 \%$ followed by a decrease. There was also a steady increase in crispiness with the increase in barrel temperature. The functional relationship between the extrusion operating conditions and crispiness score was described by a quadratic polynomial $\left(\mathrm{R}^{2}=0.99\right.$ and Adjusted $\mathrm{R}^{2}=$
0.96). Temperature, feed moisture, blending proportion and quadratic term of the blend proportion had significant $(p<0.05)$ influence on the texture. The values of the model coefficients and the degree of fit are presented in Table 2.

\subsubsection{Overall acceptability (OAC)}

The OAC score is presented in Table 3. The extrusion conditions had a significant influence on OAC. The maximum acceptability score was $7.7 \pm 1.34$ (between "like moderately" and "like very much") at $140^{\circ} \mathrm{C}$ temperature, $25 \mathrm{t} / 75 \mathrm{r} \%$ blend ratio and $21 \%$ feed moisture content though not significantly different from other treatments at high rice percentage and barrel temperature (Table 2). The minimum was $3.2 \pm 0.89$ (between "dislike slightly" and "dislike moderately") at $140 / 150^{\circ} \mathrm{C}$ temperature, $100 \%$ teff and $21 \%$ feed 
moisture content. In general, overall acceptability increases with increase in rice proportion and extrusion temperature (Figure 4a). The relationship between overall acceptability and the operating conditions as described by a two-factor interaction model (2FI) $\left(\mathrm{R}^{2}=\right.$ 0.82 and Adjusted $\mathrm{R}^{2}=0.63$ ) (Table 2).

\subsection{Correlation of variables}

The association between the different quality attributes of extrudates is presented in Table 4. Expansion ratio was negatively and strongly $(p<0.01)$ correlated to $\mathrm{BD}$ and texture indicating the wellexpanded products had a lower weight per unit volume and they required lower force to break. Expansion ratio was positively correlated $(\mathrm{p}<0.05)$ with WAI which attributed to the air spaces formed as a result of expansion were available to hold the absorbed water. BD was strongly $(p<0.01)$ associated with all the variables except SL. There was a positive association between BD and texture (the force required to break the extrudates) and WSI. BD was negatively associated with WAI indicating the less dense and expanded extrudates had a tendency to absorbed more water due to a large number of air cells available. Moreover, less dense products exhibited higher sensory scores. The texture was strongly $(p<0.01)$ associated with the sensory attributes and physico-chemical properties indicating that texture is an important quality attribute for extruded products.

\subsection{Optimization}

\subsubsection{Graphical optimization}

The optimum combination of extrusion temperature, feed moisture content and blend proportion that gives the best product in view of the sensory attributes and physicochemical properties was obtained by superimposing the response surfaces of the sensory
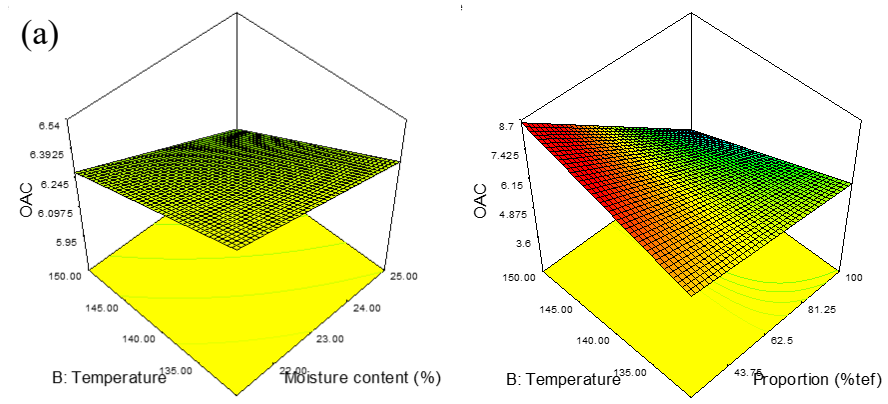

(b)
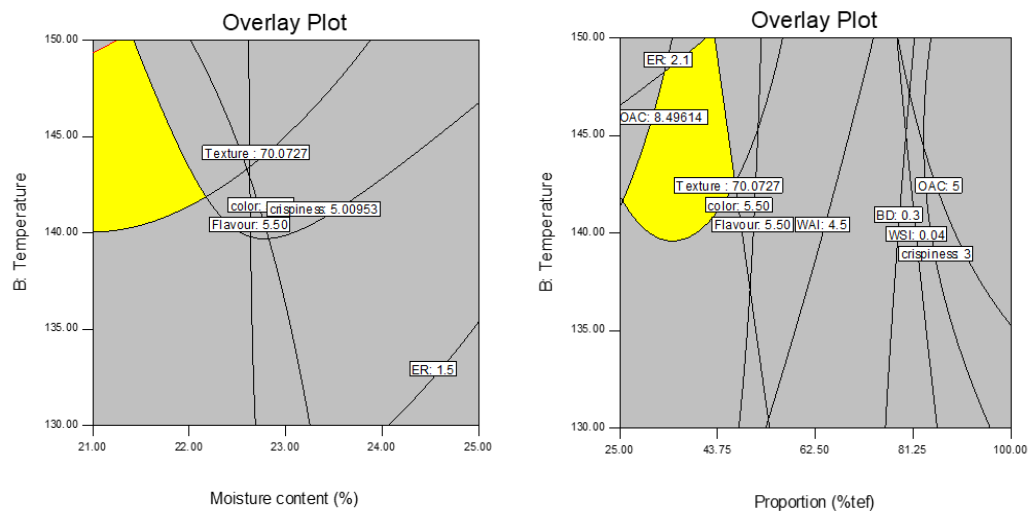

Figure 4. Response surface for Overall Acceptability (a) and Overlay plots showing optimal region

Table 4. Correlation coefficients between variables

\begin{tabular}{|c|c|c|c|c|c|c|c|c|c|c|}
\hline & ER & SL & $\mathrm{BD}$ & Texture & WAI & WSI & Flavour & Colour & Crispiness & OAC \\
\hline ER & 1 & & & & & & & & & \\
\hline SL & -0.266 & 1 & & & & & & & & \\
\hline $\mathrm{BD}$ & $-0.426^{* *}$ & -0.292 & 1 & & & & & & & \\
\hline Texture & $-0.613^{* *}$ & 0.005 & $0.797^{* *}$ & 1 & & & & & & \\
\hline WAI & $0.330^{*}$ & 0.247 & $-0.845^{* *}$ & $-0.710^{* *}$ & 1 & & & & & \\
\hline WSI & -0.18 & -0.221 & $0.846^{* *}$ & $0.689^{* *}$ & $-0.873^{* *}$ & 1 & & & & \\
\hline Flavour & 0.047 & 0.001 & $-0.863^{* *}$ & $-0.883^{* *}$ & $0.657^{*}$ & $-0.879^{* *}$ & 1 & & & \\
\hline Colour & 0.173 & -0.189 & $-0.734^{* *}$ & $-0.816^{* *}$ & 0.547 & $-0.726^{* *}$ & $0.768^{* *}$ & 1 & & \\
\hline Crispiness & 0.076 & 0.161 & $-0.874^{* *}$ & $-0.800^{* *}$ & $0.616^{*}$ & $-0.865^{* *}$ & $0.919^{* *}$ & $0.667^{*}$ & 1 & \\
\hline $\mathrm{OAC}$ & 0.058 & -0.002 & $-0.854^{* *}$ & $-0.887^{* *}$ & $0.578^{*}$ & $-0.849^{* *}$ & $0.942^{* *}$ & $0.861^{* *}$ & $0.875^{* *}$ & 1 \\
\hline
\end{tabular}

**. Correlation is significant at the 0.01 level (2-tailed)

*. Correlation is significant at the 0.05 level (2-tailed) 
attributes and physicochemical properties contour plots. The optimum region is shown in the yellow shaded area of Figure 4b. The optimization criteria used were sensory attributes greater or equal to the "like" score, minimized $\mathrm{BD}$, Texture and WSI, maximized WAI and ER. The graphical optimization revealed that the best results were found for between 140 to $150^{\circ} \mathrm{C}, 21$ to $22 \%$ feed moisture and 25 to $46 \%$ of teff proportion.

\subsubsection{Numerical optimization}

For numerical optimization all the sensory attributes, WAI and ER were maximized and Texture, BD and WSI were minimized. The numerical optimization revealed that the optimal extrusion conditions for the best result were extrusion temperature of $150^{\circ} \mathrm{C}$, feed moisture content of $21.2 \%$ and the blending ratio of $40 \%$ teff with a desirability value of 0.901 .

\section{Conclusion}

The physicochemical properties and sensory acceptability were significantly $(p<0.05)$ influenced by the extrusion conditions. Increase in barrel temperature and a decrease in moisture content increased the expansion ratio. Increase in the proportion of teff resulted in a decrease in ER. The WAI increased with the increase in extrusion temperature, feed moisture content and proportion of rice flour. High extrusion temperature, low moisture content and high teff proportion resulted in increased WSI. Results for flavor, colour, crispness and overall acceptance revealed that significant differences exist between the products due to extrusion conditions. The graphical optimization revealed that the best results were found for between 140 to $150^{\circ} \mathrm{C}, 21$ to $22 \%$ feed moisture and 25 to $46 \%$ of teff proportion. The numerical optimization revealed that the optimal extrusion conditions for the best result were extrusion temperature of $150^{\circ} \mathrm{C}$, feed moisture content of $21.2 \%$ and the blending ratio of $40 \%$ teff with a desirability value of 0.901 .

\section{References}

Ali, Y., Hanna, M.A. and Chinnaswamy, R. (1996). Expansion Characteristics of extruded corn grits. LWT - Food Science and Technology, 29(8), 702707. https://doi.org/10.1006/fstl.1996.0109

Anderson, R.A.B.S., Conway, H.F.B.S. and Peplinski, A.J.B.S. (1969). Gelatinization of corn grits by roll and extrusion cooking. Starch - Stärke, 22(4), 130 135. https://doi.org/10.1002/star.19700220408

Asrat, F. and Frew, T. (2001). Utilization of teff in Ethiopian diet. In, Narrowing the rift, Teff research and development, presented at International
Workshop on teff Genetics and Improvement. Debre zeit, Ethopia.

Awolu, O.O., Oluwaferanmi, P.M., Fafowora, O.I. and Oseyemi, G.F. (2015). Optimization of extrusion process for the production of ready-to-eat snack from rice, cassava and kersting's groundnut composite flours. LWT - Food Science and Technology, 64(1), 18-24. https://doi.org/10.1016/j.lwt.2015.05.025

Bhattacharya, S. and Choudhury, G.S. (1994). Twinscrew extrusion of rice flour, effect of extruder length-to-diameter ratio and barrel temperature on extrusion parameters and product characteristics. Journal of Food Processing and Preservation, 18(5), 389-406. https://doi.org/10.1111/j.17454549.1994.tb00261.x

Bultosa, G. (2016). Teff, Overview. In Wrigley, C., Corke, H., Seetharaman., K. and Faubion, J. (Eds). Encyclopedia of food grains, p. 281-289. Oxford, United Kingdom: Elsevier

Dalbhagat, C.G., Mahato, D.K. and Mishra, H.N. (2019). Effect of extrusion processing on physicochemical, functional and nutritional characteristics of rice and rice-based products, A review. Trends in Food Science and Technology, 85, 226-240. https:// doi.org/10.1016/j.tifs.2019.01.001

Ding, Q.-B., Anisworth, P., Tucker, G. and Marson H. (2005). The effect of extrusion conditions on the physicochemical properties and sensory characteristics of rice-based expanded snacks. Journal of Food Engineering, 66(3), 283-289. https://doi.org/10.1016/j.jfoodeng.2004.03.019

Dziezak, J.D. (1991). Romancing the kernel, a salute to rice varieties. Food Technology, 45, 74-80.

Gbenyi, D.I., Nkama, I. and Badau, M.H. (2017). Effect of feed moisture, variety and single screw extrusion on physicochemical extrusion properties and acceptability of grain sorghum. International Journal of Food Science and Nutrition, 2, 130-135.

Gebremariam, M.K., Zarnkow, M. and Becker, T. (2014). Teff (Eragrostis teff) as a raw material for malting, brewing and manufacturing gluten-free foods and beverages, a review. Journal of Food Science and Technology, 51, 2881-2895. https:// doi.org/10.1007/s13197-012-0745-5

Gopirajah R. and Muthukumarappan, K. (2017). Effect of extrusion process conditions on the physical properties of tef-oat healthy snack extrudates. Journal of Food Processing and Preservation, 42(3), ee13559. https://doi.org/10.1111/jfpp.13559

Hagenimana, A., Ding, X. and Fang T. (2006). Evaluation of rice flour modified by extrusion cooking. Journal of Cereal Science, 43(1), 38-46. 
https://doi.org/10.1016/j.jcs.2005.09.003

Kadan, R.S., Bryant, R.J. and Pepperman, A.B. (2003).

Functional properties of extruded rice flour. Journal of Food Science, 68(5), 1669-1672. https:// doi.org/10.1111/j.1365-2621.2003.tb12311.x

Kebede, L. Solomon, W., Bultosa, G. and Yetneberk, S. (2010). Effect of extrusion operating conditions on the physical and sensory properties of tef (Eragrostis tef [Zucc.] Trotter) flour extrudates. Ethiopian Journal of Applied Science and Technology, 1(1), 27-38

Köksel, H, Ryu, G.H., Başman, A., Demiralp, H. and Perry, K.W.N. (2004). Effects of extrusion variables on the properties of waxy hulless barley extrudates. Food/Nahrung, 48(1), 19-24. https:// doi.org/10.1002/food.200300324

Lei, H., Fulcher, R.G., Ruan, R. and Lengerich B. (2005). SME-Arrhenius model for WSI of rice flour in a twin-screw extruder. Cereal Chemistry, 82(5), 574-581. https://doi.org/10.1094/CC-82-0574

Liu, C., Zhang, Y., Liu, W., Wan, J, Wang, W., Wu, L., Zuo, N., Zhou, Y. and Yin, Z. (2011). Preparation, physicochemical and sensory properties of texturized rice produce by improved extrusion cooking technology. Journal of Cereal Science, 54 (3), 473-480. https://doi.org/10.1016/ j.jcs.2011.09.001

Mason, W.R. and Hoseney, R.C. (1986). Factors affecting the viscosity of extrusion-cooked wheat starch. Cereal Chemistry, 63(5), 436-441.

Moraru, C.I. and Kokini, J.L. (2003). Nucleation and expansion during extrusion and microwave heating of cereal foods. Comprehensive Reviews in Food Science and Technology, 2(4), 147-165. https:// doi.org/10.1111/j.1541-4337.2003.tb00020.x

Ollet, A.L., Li, Y., Parker, R., Smith, A.C., Miles, M.J. and Morires, VM. (1990). Macrostructual changes during the twin screw extrusion cooking of maize grits. Carbohydrate Polymers, 13(1), 69-84. https:// doi.org/10.1016/0144-8617(90)90052-T

Robin, F., Théoduloz, C. and Srichuwong, S. (2015). Properties of extruded whole grain cereals and pseudo cereals flours. International Journal of Food Science and Technology, 50(10), 2152-2159. https:// doi.org/10.1111/ijfs. 12893

Seifu, K. (1993). Teff breeding, genetic resources, agronomic utilization and role in Ethiopian agriculture. Addis Ababa, Ethiopia: Institute of Agricultural Research.

Seifu, K. (1997). Teff (Eragrostis teff [Zucc.] Trotter): Promoting the conservation and use of underutilized neglected crop, 12. Italy: IPGRI.
Singh, J.P., Kaur, A., Shevkani, K., Singh, N. and Singh, B. (2016). Physicochemical characterization of corn extrudates prepared with varying levels of beetroot (Beta vulgaris) at different extrusion temperatures. International Journal of Food Science and Technology, 51(4), 911-919. https://doi.org/10.1111/ ijfs. 13051

Sisay, M.T., Emire, S.A, Ramaswamy, H.S. and Workneh, T.S. (2018). Effect of feed components on quality parameters of wheat-tef-sesame-tomato based extruded products. Journal of Food Science and Technology, 55, 2649-2660. https:// doi.org/10.1007/s13197-018-3187-x

Suksomboon, A., Limroongreungrat, K., Sangnark, A., Thititumjaria, K. and Noomhorm A. (2011). Effect of extrusion conditions on the physicochemical properties of a snack made from purple rice (Ho mil) and soybean flour. International Journal of Food Science and Technology, 46(1), 201-208. https://doi.org/10.1111/j.1365-2621.2010.02471.x

Wondimu, A. and Emire, S.A. (2016). Process parameters optimization for the manufacture of extruded teff-based gluten-free snacks. Advance Journal of Food Science and Technology, 4, 299307. https://doi.org/10.19026/ajfst.11.2414

Zewdu, A.D. and Solomon, W.K. (2007). Moisturedependent physical property of teff seed. Biosystems Engineering, 96(1), 57-63. https://doi.org/10.1016/ j.biosystemseng.2006.09.008 